\title{
三次元円検出による部品位置決めと事前のハンド干渉チェック により実現した視覚ベースビンピッキングシステム
}

\author{
恩 田 寿 和* 藤 原 伸 行* 阿 部 清 秀* 森 宣 仁*

\section{Vision Based Bin-Picking System Supported by Three Dimensional Circle Detection and Previously Collision Avoidance}

\author{
Toshikazu Onda*, Nobuyuki Fujiwara*, Kiyohide Abe* and Nobuhito Mori*
}

\begin{abstract}
We have developed a complete automated vision based bin-picking system including vision system, planning system and manipulator system. The vision system detects and locates $3 \mathrm{D}$ circle on the object using stereo ranging technique. The planning system checks collisions between the manipulator and a bin with respect to each detected parts to select most suitable one for picking. Then, the manipulator successfully picks up parts one after another. This paper describes our unique approach to detect parts, picking strategy and experimental results to show its advantages
\end{abstract}

Key Words: Bin-Picking, Factory Automation, Castings, Planning, 3D-Vision

1.はじめに

ファクトリーオートメーションの分野では，視覚センサを使 用したハンドリングシステムが多く導入されている，我々はこ れまでに，特にモータのケーシングに代表される鋳造部品の製 造工程において，モデルベーストマッチング法を適用してベル トコンベア上や作業台上に置かれた部品を把持する視覚ベース のハンドリングシステム $[1]$, ステレオ計測を使用して対象部品 の基準面を検出することによりランダムに置かれた部品の位置 決めを行う方式 $[2]$, 部品箱にランダムに入れられたパイプ部品 の円形の開口部を三次元円として検出する方法 [3] [4]，をそれぞ れ提案してきた，我々は，カメラ画像中に三次元円を検出する ために，まず入力画像のエッジ検出を行い，得られるエッジ画 像中の閉曲線を抽出し, 抽出した閉曲線上の点のステレオ計測 を行い，閉曲線がのる三次元平面を最小二乗法により求め，そ の平面上で閉曲線を円に近似する，という手順で処理を行った。 こうして検出される円は三次元位置と傾きの情報を持つ「三次 元円」であり，これにより文献 [3] では三次元円を開口部とする パイプ部品の位置を検出した。

Fig.1のように，カゴ型のボックスパレットの中にランダム に入れられた部品をマニプレータが拾い上げる作業は一般にビ ンピッキングと呼ばれ画像処理応用の立場で多くの研究報告が ある. Bollesらは, 対象物の CAD モデルをもとにこれを構成

原稿受付 1999 年 8 月 12 日

*株式会社明電舎

*MEIDENSHA CORPORATION
する「面」とレーザレンジファインダで計測した距離画像との マッチングをとることで，カゴの中にランダムに入机られた鋳

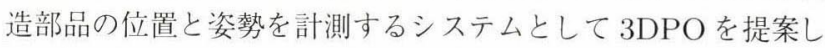
た[5].また，対象物のモデルを楕円で構成して画像中の棈円を 検出する Porrill らの TINA [6]や, 複雑な形状をしている鋳造 部品の特徵的な形状を使用する Raharadja らの simple visual cue を使用する方法 [7], などの報告がある.

しかしながら，画像処理のアプローチに比べてハンドリング作 業自体に関する報告は多くない. ビンピッキングは本来, Fig. 1 のように箱の中にランダムに入れられた対象物を取り上げる動 作であり, 視覚システムで検出してもハンドが箱に干渉して対

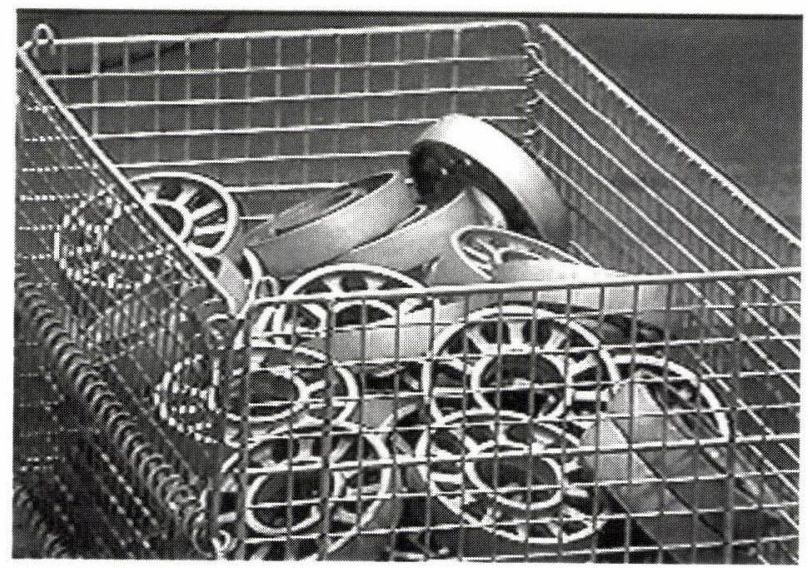

Fig. 1 Pulley parts and its box pallet 
象物に到達できないなどハンドリングできない場合が多く存在 する。このような場合実際の製造現場では, システムは動作を 停止して警報ブザーなどでオペレータを呼び, オペレータは手 動でマニプレータを箱から退避させてから箱の中の部品を整理 し, 再スタートさせる操作を行うことになる。この動作は, 製 造工程の能率を下げる原因になるため, 製造工程の自動化の大 きな阻害要因になっている。

そこで我々は, 視覚センサが検出した部品を把持する前に, そ の部品を把持する動作とマニプレータの姿勢を計算し，マニプ レータと部品の入ったボックスパレットとの干涉チェックを行 うことを考えた。これにより，マニプレータは部品を把持する 際にボックスパレットとの干渉が起こらない部品を選択してハ ンドリングすることが可能となる，さらに，干渉を含む異常が 発生したときに作業が中断することを回避するために，ハンド 部に力覚センサを設置し, マニプレータの異常な状態や動作を 検知したときに自動で復帰するシーケンスを組んだ。センサが 異常を検知したときには, マニプレータの動作をそこで中断し てカゴからマニプレータを退避させ, 再度視覚センサによる部 品検出を行う動作を自動で行うものである.

本稿では, 我々のビンピッキングシステムの基本的な考え方 について述べた後に, 視覚システムによる部品の三次元的な位 置姿勢の検出方法, 事前の干渉チェック, 自己復帰動作, につい て記述し，箱の中のすべての部品を次々に最後の一つまで取り 出す一連の作業の完全自動化を達成した実験結果を報告する.

\section{2. ビンピッキングシステムの基本的な考え方}

我々は, ビンピッキング作業をオペレータの補助なしで完全 自動で実現するために，ビンピッキングシステムをビジョンシ ステム, プランニングシステム, マニプレータシステムの三つ のシステムで構成した。 ビジョンシステムは対象物の三次元的 な位置と姿勢を決定するために，画像処理による二次元の閉曲 線抽出技術と 2 台のカメラを使用するステレオ計測技術を使用 して，対象物表面に視認できる三次元円を入力画像中に複数個 検出する.プランニングシステムは, ビジョンシステムが検出し た複数の対象物候補の中からそのひとつひとつについて，それ をハンドリングするときのマニプレータの姿勢を計算し, 単純 化したマニプレータモデルを使用してマニプレータ各部とボッ クスパレットとの干涉チェックを行うことにより, 干渉が起こら ない部品を選択する。マニプレータシステムはこれを受け, 選 択された部品をハンドリングし，加工機にセットするなどの作 業を行う。このときマニプレータが部品のハンドリングに失敗 した場合も，マニプレータに設置されたセンサにて異常を検知 し，製造工程を停止させることなく自動的にハンドリング作業 を中止し，マニプレータをボックスパレットから退避させ，再 度ビジョンシステムによる部品検出から始まる作業を再開する. これらにより, 我々のビンピッキングシステムはボックスパレッ トの中の部品を最後の一つまで, システムを止めることなく拾 い出すことが可能になった。

これらの工夫により我々のビンピッキングシステムは, 実用 面で大きな効果を発揮する三つのユニークな機能を持つことと なった，第一はモー夕の構成部品など円盤形状の鋳造部品をター
ゲットとして対象部品の位置と姿勢を決定するために視覚セン サを使用して画像中の三次元円を検出する機能, 第二はマニプ レータがボックスパレットと干涉せずに部品をハンドリングす るために事前に干渉チェックを行い視覚システムで検出した複 数の部品候補の中から干涉のない部品を選択してハンドリング する機能，第三はハンドリングに失敗したときにもこれを検知 して自己復帰する機能である.

\section{1 部品検出方法と対象部品の制約条件}

我々の工場におけるビンピッキング作業対象の部品はモー夕 とその駆動系, 伝達系の部品で, これらは多くの場合円盤型の 形状で中心部分にモータシャフトや伝達軸または軸受けが通る 大きな穴があいている.そこで我々はこの大きな穴に着目し, 画 像中に視認できる円形の穴を部品の位置決めに使用することに した [3].つまり, 部品を三次元空間に存在する円として考え, その中心点で位置を, 円がのる平面の法線ベクトルで方向を表 すことにした．Fig. 2 は伝達系の鋳造部品の一つでプーリと呼 ばれる対象部品とその三次元円モデルを示したものである。

部品の三次元視覚位置決めに関してはこれまでに, 部品表面 に視認できる線分や楕円に代表される edge segmentを使う方 法や三次元の曲線を conic 関数にあてはめる方法など多くの研 究報告がある。しかしながら従来の方法では計算により決定す るパラメー夕の数が多く, そのため一つの部品あたりの位置決 め計算時間が膨大であることと, ステレオ計測により得られる 計測点の精度が画像の量子化誤差の影響を受けるため部品が小 さな場合は一定以上の位置決め精度が得られない問題があった。 ビンピッキングにおいては, 作業を一定の時間内で完了させる 必要があることと, 一画面中に十数個の部品が存在するので画 面中の相対的な部品の大きさが小さいことの理由で従来方法が 適用できなかった。例えば Fig. 8で検出する三次元円の半径は 20 画素程度である。これに対して我々が文献 [3] で提案した三 次元円検出による方法は, いったん三つのパラメータで平面を 近似しておき次の三つのパラメータで円を計算するもので, 一 度に 6 個のパラメータを決定する conic あてはめなどの近似計 算に比べて $1 / 4$ 以下の時間で計算可能で, コンピュータによる べき乗の計算中に発生するビット落ちの影響もない。これは特 にビンピッキングのように一画面中に 10 個以上の部品を検出す る場合に効果が顕著に現れる。また，パラメータ数に対する計 測点の数は conic あてはめの場合の 2 倍以上が使用できるので, 量子化誤差が平滑化されて位置決め精度が良い利点がある.

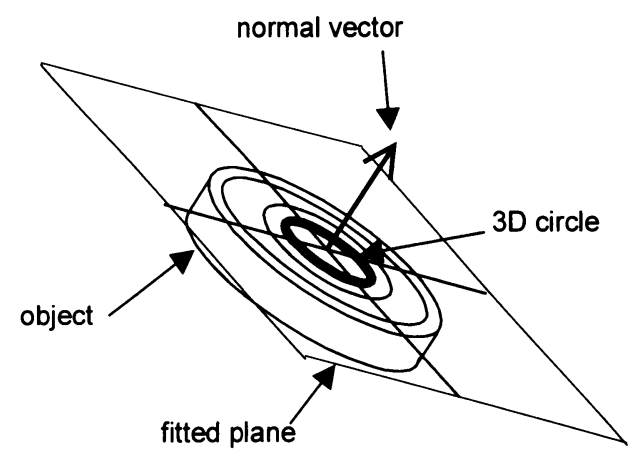

Fig. 2 3D circle model 
ところで, 今回のビンピッキングシステムの構築にあたって は現場の状況を分析し, 以下の点を制約条件として設定した。こ れらは本システムの適用の限界を示すものである。ただしこれ らの制約条件は我々の現場に固有の特別なものではなく，大多 数の一般的な工場内のビンピッキング作業にあてはまる.

1) ハンドリング対象部品は既知であること. システムは対象 部品に関する形状, 大きさ, 色, 幾何学的な特徴, 容量, 表面状態, などの情報をあらかじめ与えられるものとす る. 通常の製造ラインにおける加工, 組立の工程では指定 された対象部品以外を扱わない.

2) ハンドリング対象部品は変形しないこと. 鋳造部品に限ら ずビンピッキングの対象となる部品は一般に一定の強度を 持ち変形しないので, 我々のシステムでは, ひも, 紙袋, 布地などのようにその形状や大きさが変化するものは扱わ ないこととする.

3）ハンドリング対象部品に軸受けや取り付けなど機械的な用 途のための大きな穴があること．システムはこの部品表面 に視認できる穴を手がかりに部品を見つけるものとする. また，この穴はマニプレータの把持部としても使用する. もし対象部品の表面に大きな穴がない場合は, 我々がこれ までに提案した他の方法を適用することができる。これ は, 低レベル画像処理により入力画像から抽出する三つの 閉曲線または閉曲線と線分を使用して対象物表面に視認で きる特徵とのマッチングを取ることで対象物の三次元位置 と姿勢を検出するものである $[8]$.

4) ハンドリング対象部品は供給されるボックスパレットの中 に存在し，外にはみ出すことがないものとする。ボックス パレットの外にはみ出た部品についてはビジョンシステム が画像の中から検出することができない.

\section{3. 三次元円検出による部品位置決め}

部品の位置決めは文献 [3] で提案した三次元円検出の手法で 行う.Fig. 3 に三次元円検出のフローチャートを示す。つまり, カメラの入力画像をエッジ検出処理しエッジ画像を取得し，エッ ジ画像から閉曲線を抽出し, 閉曲線上の点のステレオ計測を行っ て各点の三次元位置を計測し, 閉曲線がのる三次元平面を近似 し，平面上に投影した閉曲線を円に近似することで，空間内の 三次元円を検出するものである.

エッジ検出は, LOG (Laplacian Of Gaussian) フィルタ,

$$
\nabla^{2} G(r)=\frac{-1}{\pi \sigma^{4}}\left(1-\frac{r^{2}}{2 \sigma^{2}}\right) \exp \left(-\frac{r^{2}}{2 \sigma^{2}}\right)
$$

により人力画像の二次微分を計算し, 計算結果のゼロ交差点を 連結してエッジ点列を抽出する。この方法はその後の特徵抽出 処理がやりやすい細く鋭いエッジが得られる利点がある.

エッジ点列から円の候補となる閉曲線を抽出するときは，エッ ジ点列が完全に閉じない場合もそれが閉曲線の一部となりうる 場合は閉曲線と同じ処理を行い円の候補とする処理を追加した， これにより照明条件の変化や影の影響でエッジ検出時に対象物 の穴が閉曲線を形成しない場合にも対処した。

抽出した閉曲線上の点のステレオ計測は 2 台のカメラを使用

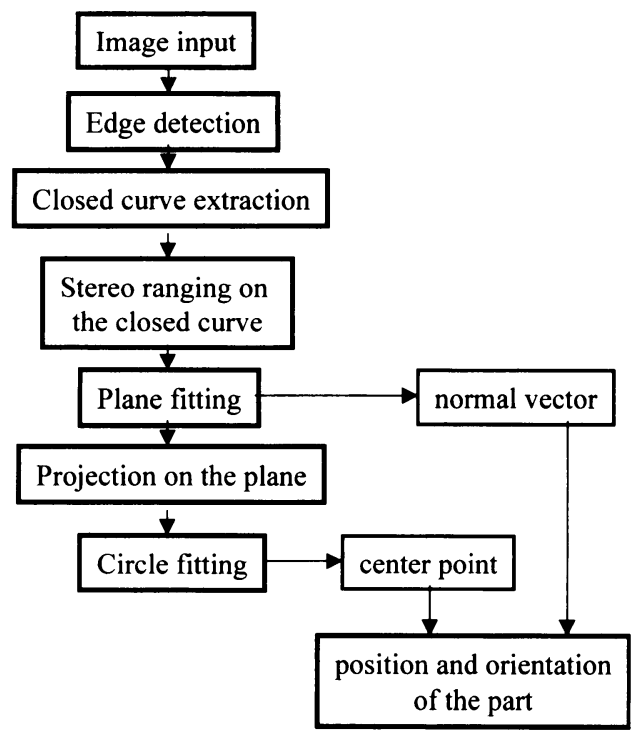

Fig. 3 Flowchart of our 3D circle detection

して行い，各点の三次元位置を計測する，さらに，計測した各 点の三次元デー夕 $\left(x_{i}, y_{i}, z_{i}\right)$ を平面に近似する。これは，対象 部品の穴が平面にのっていることによるもので，抽出した閉曲 線が対象部品の三次元円ならばこれを平面に近似することがで きる．線形回帰法 [9]によれば平面の方程式を

$$
a x+b y+c z=d
$$

としたときの係数は, 閉曲線上の計測点の各座標値の平均 $\bar{x} \bar{y} \bar{z}$, 分散 $\sigma_{x} \sigma_{y} \sigma_{z}$, 相関係数 $r_{x y} r_{y z} r_{z x}$ を用いて,

$$
\begin{aligned}
& a=\frac{r_{z x}-r_{x y} r_{y z}}{\sigma_{x}}, b=\frac{r_{y z}-r_{x y} r_{z x}}{\sigma_{y}}, c=\frac{r_{z x}^{2}}{\sigma_{z}} \\
& d=a \bar{x}+b \bar{y}+c \bar{z}
\end{aligned}
$$

と表現できる。ここで，

$$
\begin{aligned}
& \bar{x}=\frac{1}{N} \sum_{i=1}^{N} x_{i}, \bar{y}=\frac{1}{N} \sum_{i=1}^{N} y_{i}, \bar{z}=\frac{1}{N} \sum_{i=1}^{N} z_{i} \\
& \sigma_{x}^{2}=\frac{1}{N} \sum_{i=1}^{N}\left(x_{i}-\bar{x}\right)^{2}, \sigma_{y}^{2}=\frac{1}{N} \sum_{i=1}^{N}\left(y_{i}-\bar{y}\right)^{2}, \\
& \sigma_{y}^{2}=\frac{1}{N} \sum_{i=1}^{N}\left(z_{i}-\bar{z}\right)^{2} \\
& r_{x y}=\frac{1}{N \sigma_{x} \sigma_{y}} \sum_{i=1}^{N}\left(x_{i}-\bar{x}\right)\left(y_{i}-\bar{y}\right) \\
& r_{y z}=\frac{1}{N \sigma_{y} \sigma_{z}} \sum_{i=1}^{N}\left(y_{i}-\bar{y}\right)\left(z_{i}-\bar{z}\right) \\
& r_{z x}=\frac{1}{N \sigma_{z} \sigma_{x}} \sum_{i=1}^{N}\left(z_{i}-\bar{z}\right)\left(x_{i}-\bar{x}\right)
\end{aligned}
$$

である。また，平面近似の結果閉曲線上の各点の近似平面から の誤差が大きい場合はその閉曲線を三次元円の候補から除外す 


\section{ることができる.}

次に，閉曲線上の計測点を近似平面上に投影し，これらの投 影点 $(x i, y i)$ を近似平面上で円に近似する. 最小二乗法 $[10] に$ よれば, 円の方程式を

$$
a x+b y+c+x^{2}+y^{2}=0
$$

とすると，

$$
\left[\begin{array}{l}
a \\
b \\
c
\end{array}\right]=-\frac{1}{m 00}\left[\begin{array}{lll}
m 11 & m 12 & m 13 \\
m 21 & m 22 & m 23 \\
m 31 & m 32 & m 33
\end{array}\right]+\left[\begin{array}{c}
\sum\left(x i^{2}+y i^{2}\right) x i \\
\sum\left(x i^{2}+y i^{2}\right) y i \\
\sum\left(x i^{2}+y i^{2}\right)
\end{array}\right]
$$

で求められる。ここで,

$$
\begin{aligned}
m 00 & =M\left(\sum x i^{2}\right)\left(\sum y i^{2}\right)+2\left(\sum x i y i\right)\left(\sum x i\right)\left(\sum y i\right) \\
& -\left(\sum x i\right)^{2}\left(\sum y i^{2}\right)-\left(\sum y i\right)^{2}\left(\sum x i^{2}\right)-N\left(\sum x i y i\right)^{2} \\
m 11 & =N \sum y i^{2}-\left(\sum y i\right)^{2} \\
m 12 & =\sum x i \sum y i-N \sum x i y i \\
m 13 & =\sum x i y i \sum \sum y i-\sum y i^{2} \sum x i \\
m 21 & =\sum x i \sum y i-N \sum x i y i \\
m 22 & =N \sum x i^{2}-\left(\sum x i\right)^{2} \\
m 23 & =\sum x i \sum x i y i-\sum x i^{2} \sum y i \\
m 31 & =\sum x i y i \sum y i-\sum x i \sum y i^{2} \\
m 32 & =\sum x i \sum x i y i-\sum x i^{2} \sum y i \\
m 33 & =\sum x i^{2} \sum y i^{2}-\left(\sum x i y i\right)^{2}
\end{aligned}
$$

である。近似円の中心 $(o x, o y)$ と半径 $r$ は $a, b, c$ を使用 して,

$$
o x=-\frac{a}{2}, \quad o y=-\frac{b}{2}, r=\frac{1}{2} \sqrt{a^{2}+b^{2}-4 c}
$$

で求めることができる.

こうして閉曲線の計測データから平面上にある円，つまり三 次元円が計算される。このとき, 近似平面の法線ベクトルが三次 元円の中心軸の方向と等しく, 近似平面上の近似円の中心が三 次元円の中心を表している。な扮平面近似の場合と同様に，円 近似の結果閉曲線から近似平面上に投影された各点の近似円か らの䛊差が大きい場合はその閉曲線を三次元円の候補から除外 することができる。

Fig. 4 から Fig. 8 は处理の過程を写真で示したものである. Fig. 4 は原画像で, カゴ型のボックスパレットにランダムに放 り込まれたプーリを，その上方に設置したカメラから撮影した 画像である、ステレオ計測のために 2 台のカメラを使用するが Fig. 4 はこれらのうちの一方のカメラの画像である. Fig. 5 は, Fig. 4 の原画像を画像処理して得られたエッジ点列の画像であ る。我々のエッジ検出処理では上述したように, LOGフィルタ

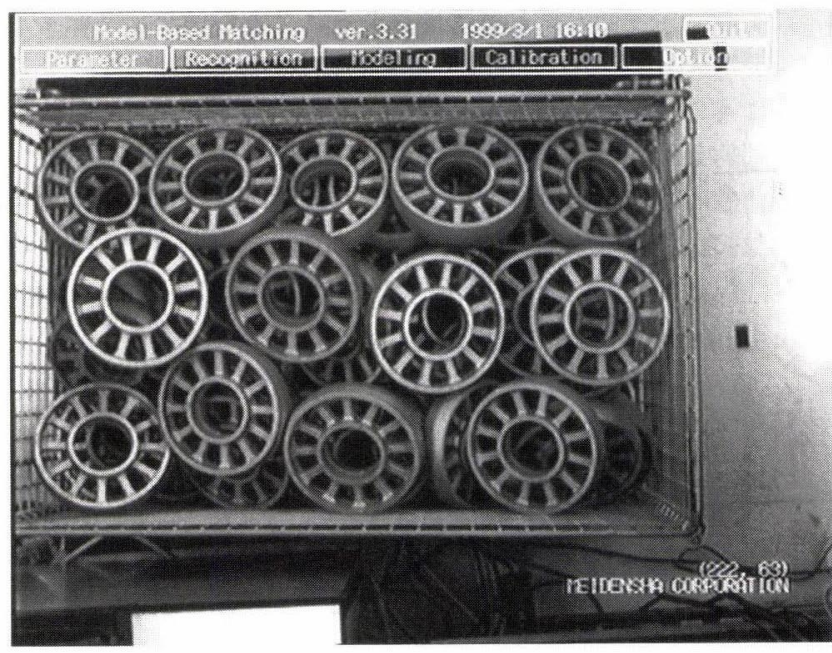

Fig. 4 Original image of the parts in a bin

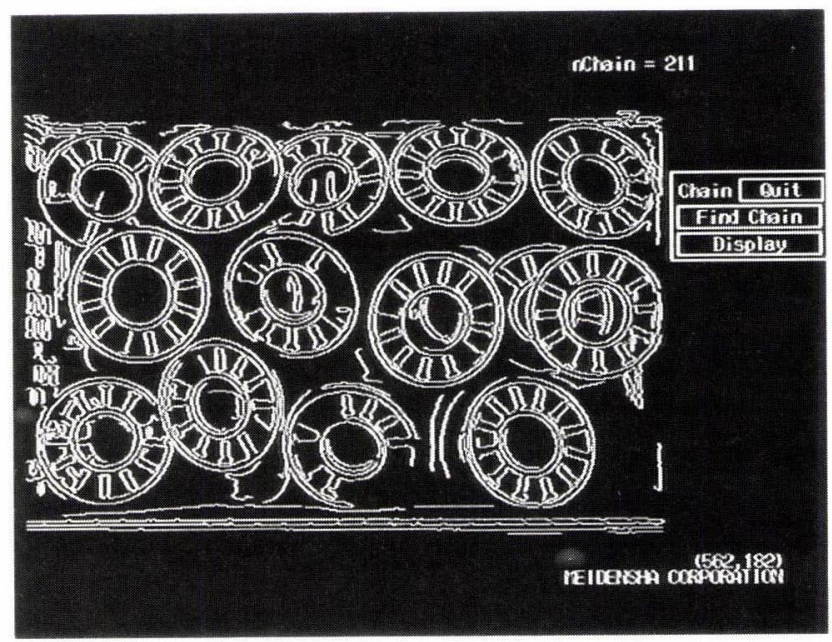

Fig. 5 Edge image of Fig. 4

を使用して二次微分処理を行った後にゼロ交差点を連結してエッ ジ点列を抽出するが，この過程で孤立したエッジ点を削除して ノイズ除去をしている。Fig.6は，Fig. 5 のエッジ画像から閉 曲線を抽出した結果である. 抽出された閉曲線は, 三次元円を 形成することが期待される閉じたエッジ点列であるが, 完全に 閉じていないがほぼ閉じているエッジ点列もそれらに加えて三 次元円の候補として抽出することにした。これにより, Fig. 6で はこれら完全に閉じていない閉曲線を含む画像中のほとんどの 三次元円の候補が抽出されている．Fig. 7 は, Fig. 6 の閉曲線 の候補から, 閉曲線上の各点のステレオ計測, 閉曲線の平面近 似, 平面への計測点の投影, 投影点の円近似を行って検出した 13 個の三次元円を, おのおのの円の中心からの矢印で示した法 線ベクトルとともに表示したものである。平面近似と円近似の 過程で多くの三次元円候補の閉曲線が, 三次元円を形成しない と判断されて排除された，Fig. 8 は Fig. 7 の三次元円検出結果 をFig. 4 の原画像にオーバーレイ表示したものである. 我々の ビジョンシステムが画像中に視認できるすべての対象物（プー リ）を正確に検出していることが分かる. 


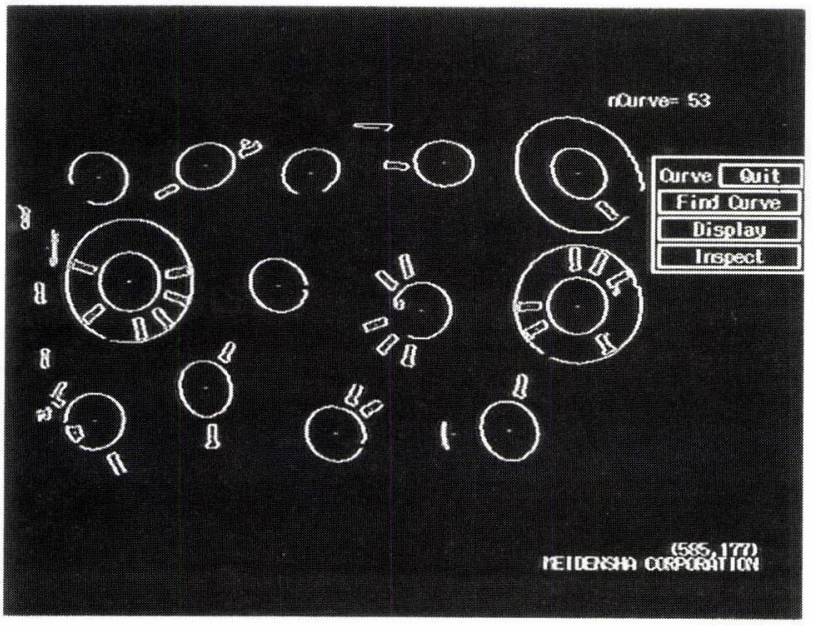

Fig. 6 Extracted closed curves from Fig. 5

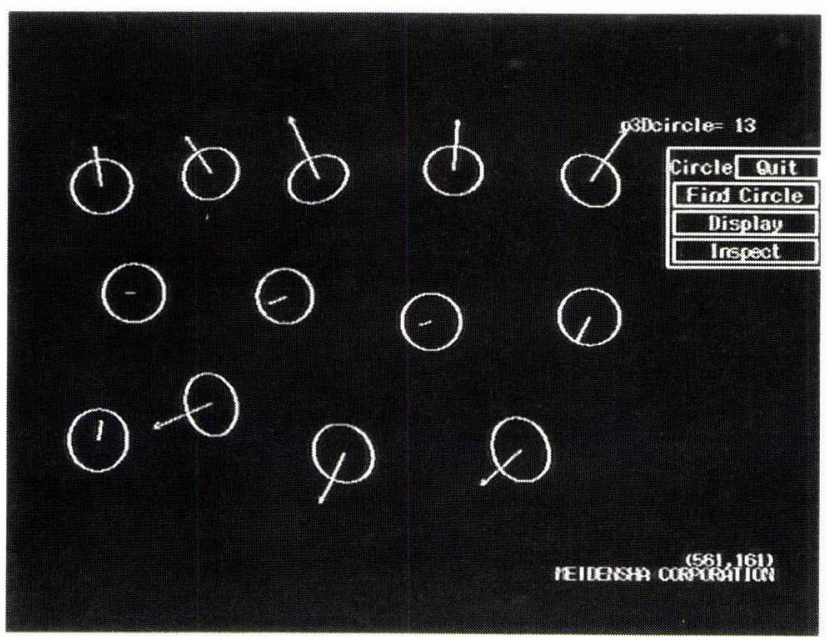

Fig. 7 Detected 3D circles

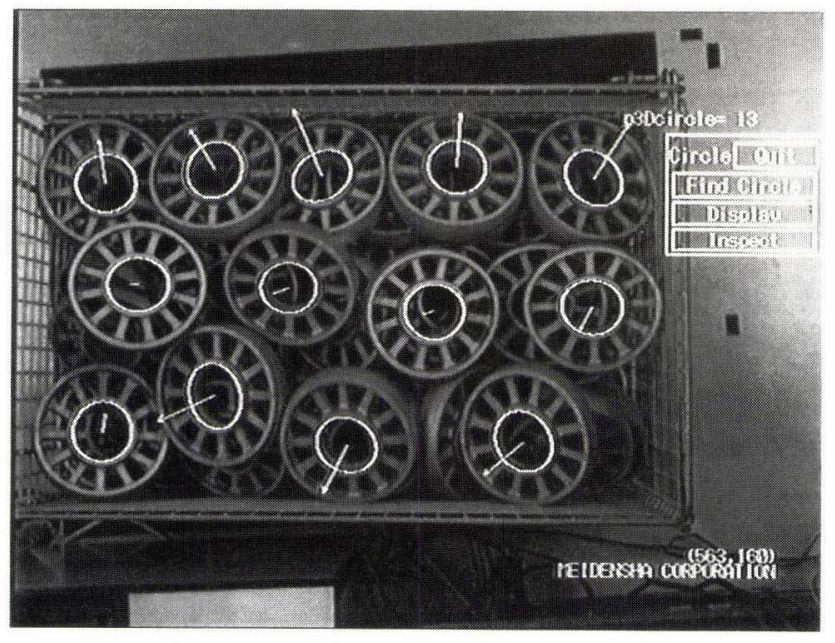

Fig. 8 Detected 3D circles on the original image

4. 事前のハンド干渉チェック

ビンピッキング作業は, まずビジョンシステムがカメラの映 像を人力してボックスパレット内に複数の対象部品 (三次元円)

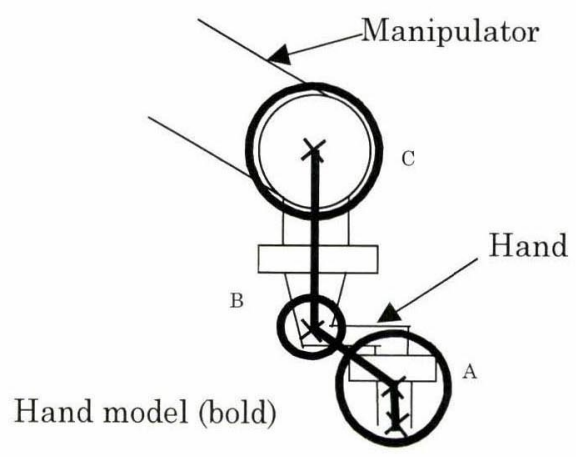

Fig. 9 Hand and its spatial model

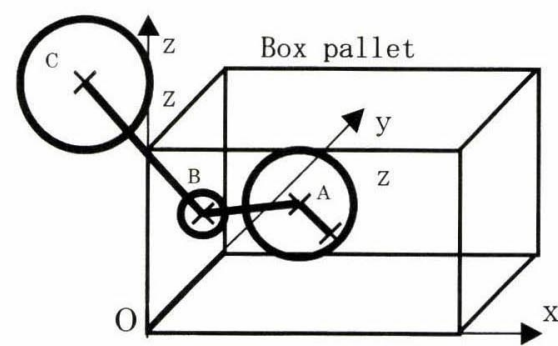

Fig. 10 Collision between hand and the box

を検出し，プランニングシステムではこれらの部品を把持する ことを想定したマニプレータの姿勢をそれぞれ計算してマニプ レータとボックスパレットとの干渉チェックを行い, 干渉の起 こらない部品を選択することにより，マニプレータシステムが これを把持し, 次工程の加工機へのローディングを行うという 連のシーケンスを順次進めていくものである.

プランニングシステムでは, ビジョンシステムが検出した部品 をマニプレータシステムがハンドリングする前に，マニプレー タとボックスパレットとの干渉なしにその部品を把持できるか 否かのチエックを行うことにした。つまり, 対象部品の位置と 姿勢が決まるとこれを把持するマニプレータの姿勢が決まるの で，このときのマニプレータとボックスパレットの位置関係は 計算することができる。そこで，我々は複雑な形状をしている ハンドを, 計算コスト削減のため, 従来より行われているよう に複数の球とこれらを結ぶビームでモデル化した. Fig.9は ンドを含むマニプレータと $\mathrm{A}, \mathrm{B}, \mathrm{C}$ の三つの球を含むハンド モデルを示したものである。これらにより複雑な形状をしてい るハンドがカバーされる．Fig. 10 は干渉チェックに拈けるハン ドモデルとボックスパレットの干渉チェック計算の模式図で, 部 品を把持する位置に扔けるハンドのすべての球とすべてのビー ムの掞のおのについてボックスパレット側面 (平面) との干渉 状態を計算し，いずれかが干渉する場合は干渉あり，すべてが 干渉しない場合に干渉なしと判断することとした。干渉状態は， ハンドモデルの球の中心とボックスパレットの各面を構成する 平面との距離 $d$ を計算し, 球の半径 $r$ との関係が， $d \leq r$ のと きに干渉ありと判断した。まず，ボックスパレットを直方体で モデル化し，この直方体に座標軸 $(x, y, z$ 軸) が平行になる 直行座標系を定義する. $x_{\min }, x_{\max }, y_{\min }, y_{\max }, z_{\min }, z_{\max }$ 
は直方体の頂点位置の最大值と最小值を示している。この座標 系に扔ける球の中心位置 $(x, y, z)$ と球の半径 $r c$ との関係が,

$$
\begin{aligned}
& x_{\min }+r_{c} \leq x \leq x_{\max }-r_{c} \\
& y_{\min }+r_{c} \leq y \leq y_{\max }-r_{c} \\
& z_{\min }+r_{c} \leq z
\end{aligned}
$$

または

$$
\begin{aligned}
& x<-r_{c}, x_{\max }+r_{c}<x \\
& y<-r_{c}, y_{\max }+r_{c}<y \\
& z_{\max }+r_{c} \leq z
\end{aligned}
$$

のときに干渉なし，そうでないときは干渉ありと判断した。

この干渉チエックにより，ハンドとマニプレータをボックス パレットに衝突させることなくハンドリングすることが可能に なった。

\section{5. マニプレータシステムの動作の改善}

これまでの自動化された製造ラインで大きな課題となってい たのは, システムに何らかの異常が発生したときにはマニプレー 夕が緊急停止し,この際オペレータによる復㷌処理が必要で, 結 果としてラインの生産効率が上がらない点だった。我々はこの 点を考慮し，マニプレータが動作中にハンドリングに失敗する などの異常が発生したときにも，これを検知してマニプレー夕 をボックスパレットの上から退避させる機能をマニプレータシ ステムに持たせた。これによりビンピッキングシステムは, 異 常発生時にもビジョンシステムによる部品検出から始まる一連 の動作を自動的に再開する。

マニプレータの動作異常検知のためにはハンド部に力覚セン サを設置し，ハンドリング動作中に力覚センサに一定以上の加 重が検出された場合，または一定以上の加重の変化が検出され た場合に動作異常と判断することにした。さらに，動作異常が 検出されたときは，マニプレータシステムはマニプレータの動 作をいったん停止し，部品を把持していればそれを開放し，力 メラ視野からマニプレータを退避させ，その後検出とハンドリ ングの動作を自動的に再開するシーケンスを組んだ. Fig. 11 はこの一連の流机を示すフローチャートである。これにより動 作異常の発生時にもオペレー夕を呼ぶことなく, 自動的に作業

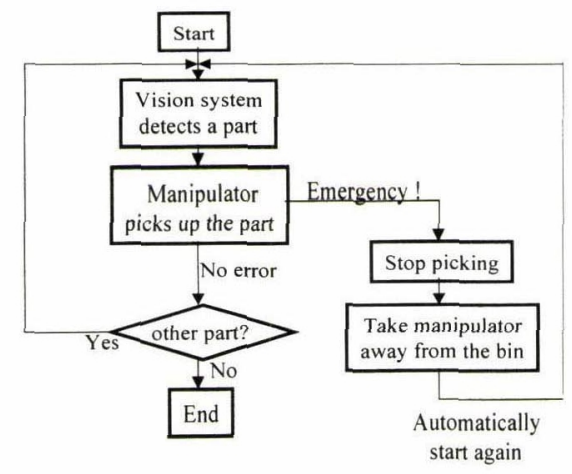

Fig. 11 Flowchart of our system
を再開する完全自動のビンピッキングシステムが実現した。才 ペレータを呼ぶことなく作業を継続することは, 実際の現場で 最も重要なことである。

6. 実

験

Fig. 12 は本システムのシステム構成図を示したものである. ビジョンシステムはマニプレータの上方に設置した 2 台のカメ ラとロボットコントローラ内に実装された画像処理装置で構成 し, 三次元円検出による部品の検出を行う。マニプレータシス テムはマニプレータ本体とロボットコントローラで構成し，口 ボットコントローラに干渉チェックとハンドリング対象部品の決 定を行うプランニングシステムが実装されている。マニプレー タのハンド部には動作異常検知のための力覚センサを設置した。 Fig. 13 は実験に使用したビンピッキングシステムの写真で，口 ボットの前面に置かれた $400[\mathrm{~mm}] \times 400[\mathrm{~mm}] \times 800[\mathrm{~mm}]$ の金 網ボックスパレット中に山積み状態で入れられたプーリ（直径 $170[\mathrm{~mm}] \times$ 厚み $40[\mathrm{~mm}])$ を, カメラ高さ $2,300[\mathrm{~mm}]$, カメラ 間隔 $600[\mathrm{~mm}]$, カメラ視野 $800[\mathrm{~mm}] \times 600[\mathrm{~mm}]$ で上方に設置 した 2 台のカメラを使用したビジョンシステムで検出し, マニ プレータがボックスパレットとの干渉を回避して一つ一つを把 持して右側の加工機にローデイングするものである. Fig. 14 は ビジョンシステムが検出した一つの部品をマニプレータが把持 するところを撮影した写真, Fig. 15はマニプレータが把持し た部品を右の模擬加工機のチャックにローディングするところ

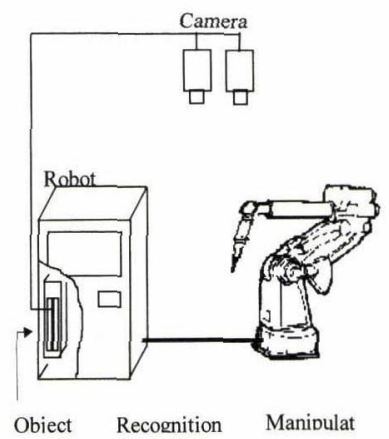

Fig. 12 System configuration of our system

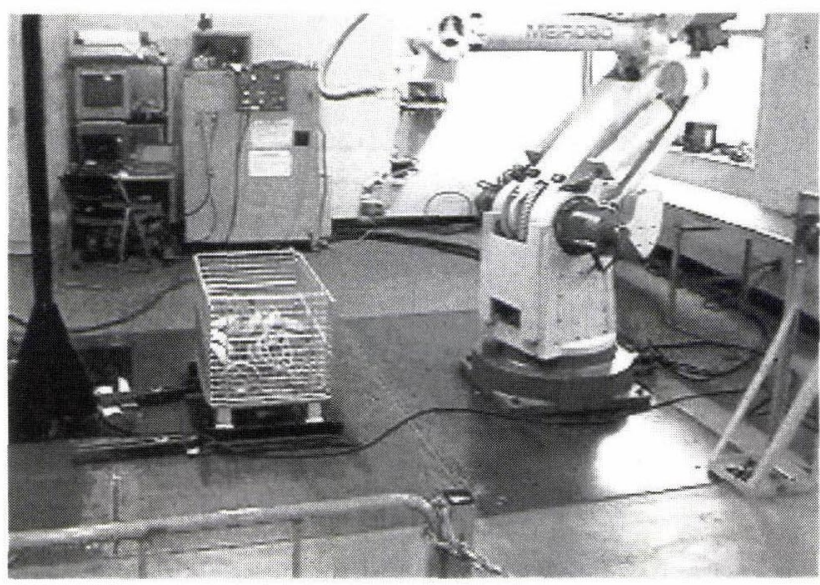

Fig. 13 Over view of our handling system in the work 


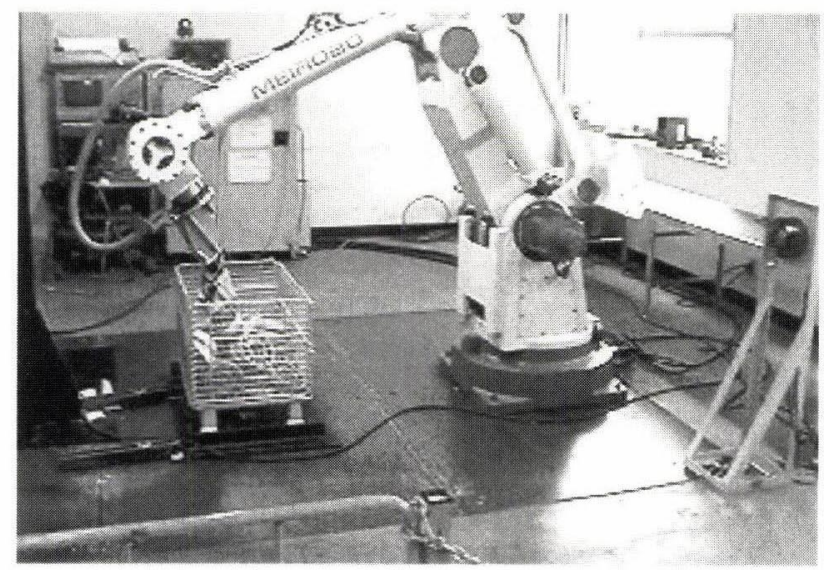

Fig. 14 Handling scene of the manipulator system

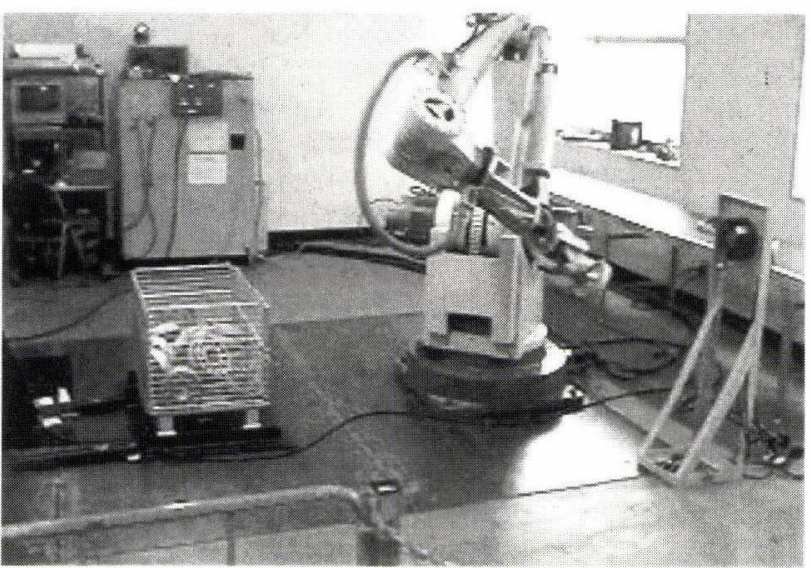

Fig. 15 Loading to the simulated processing machine

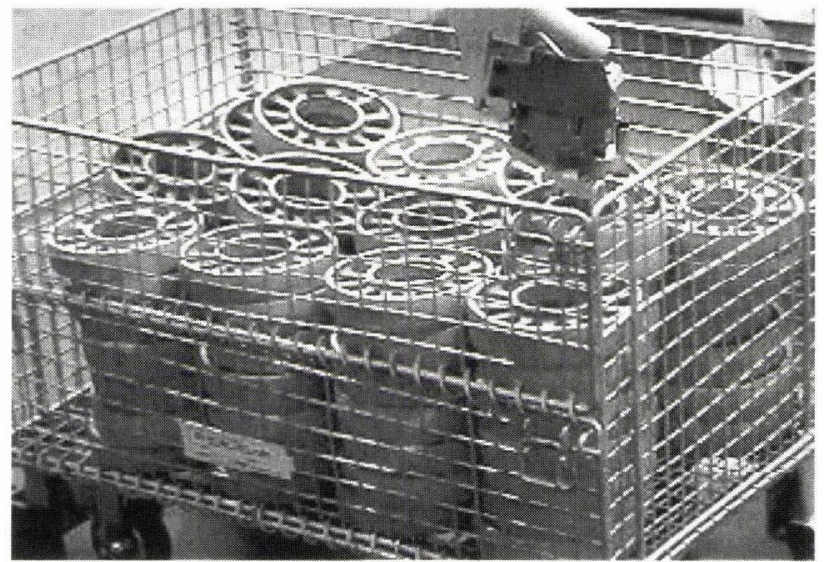

Fig. 16 Handling scene of the part in the box pallet

を撮影した写真である。

Fig. 16〜18 はハンドが部品を把持する動作を撮影した写真 である.Fig. 16 は部品がマニプレータの前面に置かれた初期の 段階の写真で, 100 個程度が比較的整然と入れられている部品 を把持している。これらの部品を画像処理で検出してハンドリ ングすることは難しくない.Fig. 17 はボックスパレットに部品 がランダムに投入された場合の写真で，部品の位置と姿勢がラ

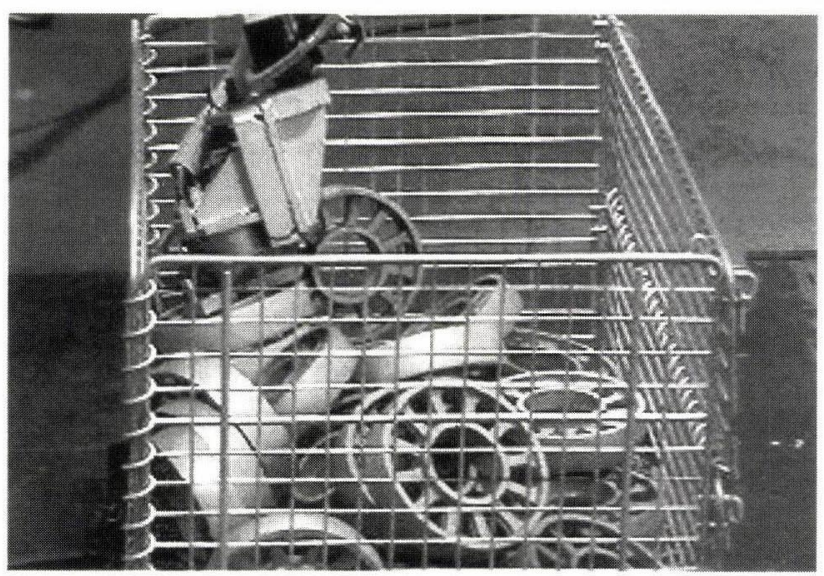

Fig. 17 Handling scene of the part on the border of the box

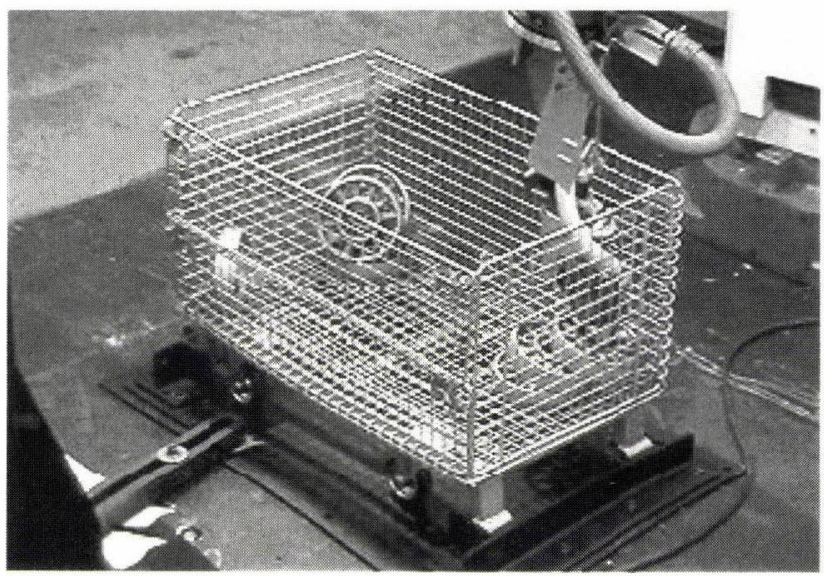

Fig. 18 Handling scene of the part in the corner of the box

Table 1 Average time costs of the system

\begin{tabular}{|c|r|}
\hline Waiting for vision & $6.0 \mathrm{sec}$ \\
\hline Communication & $0.5 \mathrm{sec}$ \\
\hline Calculation of collision & $1.7 \mathrm{sec}$ \\
\hline Approach motion & $9.2 \mathrm{sec}$ \\
\hline Picking up motion & $5.8 \mathrm{sec}$ \\
\hline \hline Total & $23.3 \mathrm{sec}$ \\
\hline
\end{tabular}

ンダムになっている。このような状況でも我々のビジョンシステ ムは部品を検出し, 三次元の位置と姿勢を正確に計測し, ハン ドもこれを正しく把持している。また，ハンドの形状に工夫が されておりボックスパレットの縁付近の部品も把持することが できている. Fig. 18 は最終段階のハンドリングの様子で, ボッ クスパレットの角付近の部品を把持している.

Table 1 はビンピッキングシステムの一つの部品を検出し把 持して搬出するまでの平均の動作時間をまとめた表である。ビ ジョンシステムの処理時間が複数の部品候補の検出と位置決め に 6.0 秒, 干渉チェックの時間が 1.7 秒, システム全体の動作 時間が 23.3 秒だった。 なお，ビジョンシステムは文献 [11]で提 案した専用のハードウエアを使用した。重量物の取り扱いのた めマニプレータの動作に時間がかかっているが, 我々の当初の 
Table 2 Numbers of collision avoidance

\begin{tabular}{|l|c|c|c|c|}
\hline Calculation & 1st & 2nd & 3rd & 4th \\
\hline \hline Total & 201 & 95 & 33 & 4 \\
\hline No collision & 106 & 62 & 29 & 0 \\
\hline Collision & 95 & 33 & 4 & 4 \\
\hline Ratio & $47.3 \%$ & $34.7 \%$ & $12.1 \%$ & $100 \%$ \\
\hline
\end{tabular}

ターゲットである鋳造部品の加工工程（タクトタイム 30 秒から 90 秒)に十分に適用できる時間である。従来の視覚位置決め方 法では数十秒かかっておりタクトタイムに間に合わなかった.

Table 2 は干渉チェックの効果を示す表で, ビジョンシステ ムが検出した 201 個のハンドリングの部品候補のうち $47.3 \% に$ あたる 95 個がハンドの干渉ありと判断され，次の候補の干渉 チェックに移行した。二番目の部品候補の干渉チェックでは 95 個のうち $34.7 \%$ にあたる 33 個が干渉ありと判断された。この ようにして，実験システムではボックスパレットに投入された すべての部品を排出することができた。干渉チェックがなけれ ば約半数の動作で干渉が発生しシステムを停止させていたこと になる。

実験の結果, 三次元円検出とハンド干渉チェックが有効に機能 して, 実験では最大四つの部品候補の中からハンドの干渉が起 こらないものを選択してハンドリングした。また，視覚システ ムの計測ミスなどによりハンドが部品を把持できなかったとき も, マニプレータをいったん退避させて次には部品を把持し, 最 終的にすべての部品を加工機にローディングすることができた

\section{7.おわりに}

ボックスパレットにランダムに投入された鋳造部品を加工機 にローディングする視覚ベースのビンピッキングシステムを実 現した. 本システムは, ビジョンシステムで三次元円検出により 部品を検出し, 事前にハンドとボックスパレットとの干渉チエッ
クを行うことで，マニプレータを停止させることなく，一つず つ正確に部品をハンドリングした。 さらに，ハンドリングに失 敗したときにもこれを検知して自己復帰する機能を搭載し, ビ ンピッキング作業の完全自動化を達成した。

\section{参 考 文 献}

[1] T. Onda, H. Igura, M. Niwakawa and N. Fujiwara: "A Handling System for Casting Parts with Feature-Based Matching," Proc. of JIASC'94, pp.71-74, 1994

[2] T. Onda, H. Igura and M. Niwakawa: "A Handling System for Randomly Placed Casting Parts Using Plane Fitting Technique," Proc. of IEEE/RSJ IROS 1995, vol.3, pp.435-440, 1995.

[3] N. Fujiwara, T. Onda and M. Niwakawa: "Three Dimensional Circle Detection and Location of Pipe Joints for Bin-Picking Tasks," Proc. of IEEE/RSJ IROS 1998, vol.2, pp.1216-1221, 1998.

[4] 藤原, 恩田, 庭川 : “ビンピッキングのためのパイプ部品の位置検出”, 第 15 回日本ロボット学会学術講演会予稿集, pp.127-128, 1997.

[5] R.C. Bolles and P. Horaud: "3DPO: A three-dimensional part orientation system," International Journal of Robotics Research, vol.5, no.3, pp.3-26, 1986

[6] J. Porrill, S.B. Pollard, T.P. Pridmore, J.B. Bowen, J.E.W. Mayhew and J.P. Frisby: "TINA: A 3D Vision System for Pick and place," Image and Vision Computing, vol.6, pp.91-99, 1988.

[ 7] K. Raharadja and A. Kosaka: "Vision-Based Bin-picking: Recognition and Localization of Multiple Complex Objects Using Simple Vision Cues," Proc. of IEEE/RSJ IROS1996, vol.3, pp.1448-1457, 1996.

[ 8 ] 恩田, 庭川：“閉曲線のマッチングによる視覚ベースハンドリングシ ステム”, 電学論 (D), vol.118-D, No.3, pp.371-376, 1998.

[9] 阿部齊著: 応用数理統計学入門. 培風館, 1985 .

[10] 恩田, 庭川, 藤原, 清家：“モデルベーストマッチング法を用いた鋳 造部品の視覚位置決め”, 電学論 (D), vol.119-D, No.1, pp.14-20, 1999.

[11] M. Niwakawa, A. Okamoto, T. Onda and N. Fujiwara: "Object Recognition for Casting Parts with Model-Based Matching," Proc. of JIASC'96, vol.2, pp.E24-E27, 1996.

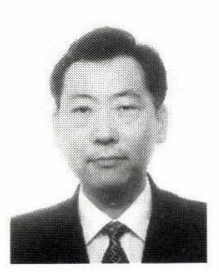

恩田寿和（Toshikazu Onda）

1954 年 2 月 10 日生. 1977 年 3 月東京工業大学電 子物理工学科卒業. 1979 年 3 月東京工業大学大学 院修士課程電子システム専攻修了。同年 (株) 明電 舎入社, 以来電子回路応用, マニプレータ制御の研 究開発を経て, 画像処理掞よびコンピュータビジョ ンの実用化開発に従事。現在，同社総合研究所副 技師長. 1997 年電気科学技術奨励賞オーム技術賞受賞. 電気学会正 員.

(日本ロボット学会正会員)

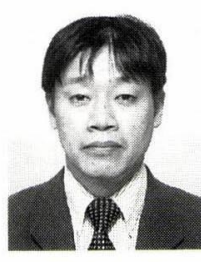

阿部清秀 (Kiyohide Abe)

1961 年 6 月 26 日生. 1984 年 3 月東京電機大学精 密機械工学科卒業. 1986 年 3 月東京電機大学大学 院修士課程機械工学専攻修了. 同年（株）明電舎入 社, 画像検査装置と画像処理装置および画像処理周 辺技術の開発に従事. 現在, 同社ロジスティクス工 場主任. 1999 年日本電機工業会電機工業技術功績 者表彰進歩賞受賞.
(日本ロボット学会正会員)

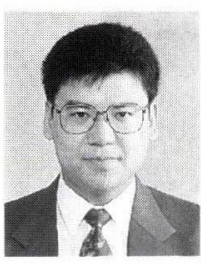

員.

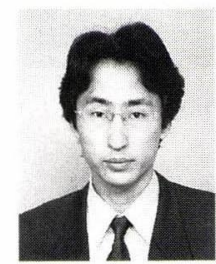

森 宣仁 (Nobuhito Mori)

1966 年 6 月 2 日生. 1990 年 3 月名古屋工業大学電気 情報工学科卒業. 同年 (株) 明電舎入社, 以来物流シ ステム，産業用ロボットおよびロボットコントローラ の開発を経て,マニプレータシステムの動作計画の研 究開発に従事. 現在, 同社ロジスティクス工場主任. 